\title{
Interpreting TARGET balances in the European Monetary Union: A critical review of the literature
}

\author{
Beniamino Moro \\ Department of Economics and Business, University of Cagliari, Viale San Ignazio 17, 09123 Cagliari, Italy
}

\section{A R T I C L E I N F O}

\section{Keywords:}

European financial crisis

Banking crises

Sovereign debt crisis

TARGET

EMU

\begin{abstract}
A B S T R A C T
This is a review article focusing on the most important studies on the role displayed by TARGET balances in the European Monetary Union (EMU). In the context of the public debt financial crisis, large TARGET balances became crucial, reflecting funding stress in the banking systems of most crisis-hit countries. The increase in TARGET balances in this period was triggered by a replacement in these countries of private sector funding of banks by central bank funding. By contrast, the more recent increases in TARGET balances are largely attributable to the implementation of the expanded asset purchase program (EAPP) by the European Central Bank (ECB), also known as a quantitative easing (Qe) monetary policy. Nevertheless, we argue that the persistency of extremely large TARGET imbalances continues to be understood by financial markets as a signal of macroeconomic distress, which should be addressed to solve the underlying tensions among EMU member States.
\end{abstract}

\section{Introduction}

Cross border payment flows between banks are a normal feature of a financially integrated area. Their settlements in the euro area create TARGET balances for each national central bank (NCB). TARGET balances are the net claims and liabilities of the euro area NCBs vis-à-vis the European Central Bank (ECB). They arise through cross-border payments settled in central bank money (CBM) of the respective national banking sectors, or the NCBs themselves, and are executed via the common euro area payment platform known as TARGET. ${ }^{1}$

When a bank makes a payment to another bank via TARGET, the current account of the payer's bank at its NCB is debited and the current account of the recipient bank at its NCB is credited. If both banks hold their current accounts at the same NCB, there is no net impact on the aggregate account of banks at the NCB, and there are no implications for TARGET balances.

However, in the case of cross-border transactions, the NCB of the paying bank sees a reduction in that bank's account at the NCB, and the NCB of the recipient bank sees an increase in the recipient bank's account. In the balance sheet of the ECB, such positions are balanced by a TARGET liability for the first NCB and a TARGET claim for the second one (ECB, 2015, p. 42).

TARGET liabilities and claims also result from cross-border transactions by NCBs themselves, such as the purchase or sale of

\footnotetext{
E-mail address: moro@unica.it, http://people.unica.it/beniaminomoro/.

URL:

${ }^{1}$ TARGET is the Eurosystem's Real-Time Gross Settlement (RTGS) system, and stands for Trans-European Automated Real-time Gross settlement Express Transfer system. It commenced operations on 4 January 1999, following the lunch of the euro. The initial TARGET system was then built by linking together the different RTGS structures that existed at the national level. It was replaced by the Eurosystem's TARGET2 platform in November 2007. During the transition period, which lasted until May 2008, all national structures were replaced by the single platform. For convenience, both TARGET and TARGET2 are here referred to as "TARGET".
} 
securities held for investment purposes. At the end of each day, such intra-Eurosystem claims and liabilities are aggregated and netted out throughout the Eurosystem. This leaves each NCB with a single net bilateral position vis-à-vis the ECB, in the form of a positive or negative TARGET balance. By design, these balances reflect the decentralized nature of the Eurosystem's operational framework, and all the TARGET balances (including the ECB's balance) at any time algebraically add up to zero (ECB, 2015, p. 42).

TARGET balances can be a consequence of the injection of large amounts of excess liquidity by the euro area's decentralized central banking systems. They emerge when the central bank reserves created in one jurisdiction (Italy for instance) flow to another (say Germany). During the sovereign debt crisis, there was a "demand-driven" increase in excess liquidity as banks substituted Eurosystem funding for market-based funding that had dried up. Although the initial provision of liquidity via refinancing operations was TARGET-neutral, TARGET balances increased as this liquidity subsequently flowed from vulnerable to less-vulnerable countries in the context of severe market stress.

However, since the start of the expanded asset purchase programme (EAPP) on the midst of 2014, particularly of the public-sector purchase programme (PSPP), implemented between 9 March 2015 and 19 December 2018, the renewed increase in excess liquidity has been predominantly "supply-driven", resulting from asset purchases by NCBs and the ECB rather than stress-related recourse to refinancing operations (Eisenschmidt, Kedan, Schmitz, \& Adalid, 2017). ${ }^{2}$

The EAPP - and in particular the PSPP - gives rise to increasing TARGET balances by inducing large cross-border liquidity flows. These flows arise, first, during the EAPP implementation and, second, via further portfolio rebalancing (ECB, 2017b, pp. 21-22). About the first case, it is important to stress that the financial structure of the euro area contributes to the current increase in TARGET balances because cross-border payments are an inherent feature of decentralized EAPP implementation in an integrated market. EAPP implementation is distinct from that of refinancing operations because it can entail immediate cross border payments, as purchases are not limited by national borders.

About the second case, it is evident that payments related to subsequent portfolio rebalancing are also affected by the financial structure and keep TARGET balances elevated. Since the launch of the EAPP, there has been a broad-based rebalancing towards noneuro area debt securities in the whole euro area, which has been driven to a significant extent by the persistently negative interest rate differentials between euro area bonds and bonds issued by other advanced economies (ECB, 2017a, pp. 41-45). Euro area residents' net purchases of non-euro area debt securities in this period have consisted almost exclusively of debt securities issued by other advanced economies, in particular the United States. Such international portfolio rebalancing usually takes place through actors located in major euro area financial centers, thereby contributing to the accumulation of reserves in particular locations and to the persistence of TARGET imbalances (ECB, 2017b, p. 24).

Therefore, the underlying factors driving the more recent increase in TARGET balances are of an intrinsically different nature with respect to those in previous episodes of rising balances. The increase in TARGET balances in the period from mid-2011 to mid-2012 was triggered by a replacement of private sector funding of banks in crisis-hit countries by central bank funding, in a period of stressed bank funding conditions. By contrast, the more recent increase in TARGET balances, beginning since mid-2014 until the end of 2018, is largely attributable to the interplay between the decentralized implementation of the EAPP - in particular the PSPP - and the financial structure of the euro area (ECB, 2017b, p. 26).

A side related problem is the huge debate in the literature on the legitimacy of the ECB's emergency powers to fight the Eurozone financial crisis, especially about the public-sector purchase programme (PSPP). Many commentators argued that this programme constituted illegal monetary financing, as the Maastricht Treaty forbids direct financing by the ECB to national States. According to the ECB, instead, the PSPP was fully within the Bank's mandate to fight any financial crisis risk.

On 11 December 2018, the European Court of Justice (ECJ) rejected the arguments that the ECB was effectively bankrolling European Governments with its PSPP and sentenced that this programme did not infringe the prohibition of monetary financing to Member States. Further, the ECJ sentenced that the ECB's questioned programme (PSPP) was in accordance with the European Union law and did not exceed the ECB's mandate. This ECJ ruling ends a long legal debate on ECB's emergency powers legitimacy. Anyway, this does not end the debate from a pure institutional and constitutional point of view. In fact, one of the deepest questions faced by any constitutional order is how to reconcile the possibility of a state of emergency with the ideals of democratic governance and rule of law.

This article is a critical review and a synthesis of the most important studies on the functioning and the interpretation of the European system of payments, called TARGET, which is unique in the world. The review includes both economic and institutionalconstitutional aspects of TARGET functioning. Its main conclusion is that, as long as the European Monetary Union (EMU) is regularly working, and due to the irreversibility of the euro, it is not necessary an annual settlement of TARGET balances from debit to credit countries, as proposed by Sinn (2012b) and Whelan (2014). The only case when a member country will be required to settle its TARGET debt is if this country decides to quit the EMU.

According to the ECB's President, Mario Draghi, «If a country were to leave the Eurosystem, its national central bank's claims on

\footnotetext{
${ }^{2}$ Around $85 \%$ of the increase in liquidity provided through euro-denominated open market operations between the end of February 2015 (i.e. prior to the commencement of the PSPP) and 31 March 2017 was due to the EAPP, which consisted of the sum of six separated programmes: the corporate sector purchase programme (CSPP), the public-sector purchase programme (PSPP), the asset-based securities purchase programme (ABSPP), and three covered bonds purchase programmes (CBPP1, 2, 3) (ECB 2019). All the increase in recourse to Eurosystem refinancing operations over the same period reflected participation in targeted longer-term refinancing operations (T-LTROs). Participation in T-LTROs should not be interpreted as a sign of stress-related recourse to Eurosystem refinancing, as the very attractive pricing of these operations was a key motive for participation (ECB, 2017b, p. 22).
} 
or liabilities to the ECB would need to be settled in full» (Draghi, 2017). But he did not specify how this settlement should be done. In fact, the only way for an EMU's member country to settle its negative TARGET balances is to sell the bonds that back the liquidity created by its NCB and, in so doing, cancel the total central bank money that its NCB issued until the moment this country is leaving the EMU.

Anyway, also excluding this hypothetical extreme breaking scenario, too much big TARGET imbalances are a manifestation of underlying tensions among member countries in the EMU, highlighting a situation of prevalent one-way direction of the liquidity from NCBs with TARGET liabilities to NCBs with TARGET claims. This situation suggests the need for macroeconomic imbalances to be addressed, trust in banking systems to be re-established, and the institutional foundations of EMU to be strengthened.

This article is organized as follows. Section 2 deals with the time evolution of TARGET balances, while Section 3 is devoted to the accumulation of TARGET imbalances during the European public debt financial crisis (2011-1012). In Section 4, we deal with the critics addressed to the ECB's management of TARGET balances during the crisis; and, in Section 5, we examine the theoretical link between TARGET balances and the balance of payments. In Section 6, the analysis focuses on the new accumulation of TARGET imbalances during the more recent quantitative easing (Qe) period (2014-2018), and in Section 7 we discuss the legitimacy of the ECB's emergency powers inside the European constitutional framework. Finally, Section 8 summarises the main points of the article and concludes.

\section{The time evolution of TARGET balances}

Table 1 summarizes the evolution of TARGET balances since 2008. From the table, we can see that there are three major countries with TARGET claims. They are: Germany (DE) with $941.3 €$ /b credit position at the end of March 2019, Luxembourg (LU) with 213.8 $€ / \mathrm{b}$, and The Netherlands (NL) with $79.9 € / \mathrm{b}$. The total claims of these major countries add up to $1235 € / \mathrm{b}$. On the other side, and at the same date, there are three major countries with TARGET liabilities, which are Italy (IT) with $-474.8 € / \mathrm{b}$ of debit position, Spain (ES) with $-401.5 € / \mathrm{b}$, and Portugal (PT) with $-80.2 € / \mathrm{b}$. The total liabilities of these countries sum up to $-956.5 € / \mathrm{b}$. After the beginning of the expanded asset purchase programme (EAPP), initiated in mid-2014, also the ECB has a negative position, which reached $-249.5 € / \mathrm{b}$ at the end of March 2019. The total algebraic sum of positive and negative positions, including ECB', at each date, always adds up to zero.

Net TARGET positions at the end of March 2019 are also depicted in Fig. 1, where the differences between the three major credit countries (to whom the central bank money is accruing), and the three major debit countries (where the central bank money is created), is emphasized. The decentralized distribution of central bank liquidity within the Eurosystem provides stability, because it allows financially sound banks, including those in countries under financial stress, to cover their liquidity needs, thereby contributing to the effective transmission of the ECB's interest rate decisions to the wider euro area economy, and facilitating the aim of maintaining price stability in the euro area over the medium term (ECB, 2013, p. 103).

Let us better explain how TARGET claims and liabilities arise with an example. Cross-border transactions always involve the ECB as the central counterpart of the system. A bank that transfers funds to a counterparty located in another country of the euro area records a reduction in its deposits with its country's NCB, while the accounts of this, in turn, record a TARGET liability towards the ECB. Conversely, a bank that receives funds records an increase in its deposits with its country's NCB, the accounts of which record a TARGET claim toward the ECB.

At close of business, each day, the credit or debit positions resulting from all the transactions are netted out, and the NCBs record, on the asset or liability side of their balance sheets, the TARGET balance, which shows a credit or a debit vis-à-vis the ECB (Cecioni \& Ferrero, 2012, p. 5).

This can be illustrated with the help of Fig. 2. Quoting Cecioni and Ferrero (2012), «in order to purchase a machinery from Firm B located in Country B, Firm A in country A asks Bank A to make a transfer from its current account (c/a) to the current account of firm $B$ in Bank B. Bank A reduces the $c / a$ of Firm A by $€ 100$; at the same time the reserve account ( $r / a)$ of Bank A at the national central bank (NCB) of Country A is reduced by $€ 100$. TARGET liabilities of NCB A increase by $€ 100$ and the ECB's TARGET claims increase by the same amount. Conversely, Bank B, which receives the $€ 100$, records an increase in its r/a at its own NCB, whose accounts record an increase of $€ 100$ of TARGET claims on the ECB (which in turn records an increase of $€ 100$ of TARGET liabilities). Finally, Bank B increases the c/a of Firm B by $€ 100 »$ (Cecioni \& Ferrero, 2012, p. 6).

These TARGET balances constitute a normal feature of the decentralized implementation of monetary policy in the euro area. They reflect cross-border financial flows within the euro area, which arise from cross-border financial transactions largely initiated by private institutions or individuals and the resultant cross-border distribution of central bank liquidity. Individual TARGET claims and liabilities of the NCBs vis-à-vis the ECB, and of the ECB vis-à-vis the NCBs, have therefore existed since the start of the European Monetary Union (EMU).

Anyway, before the sovereign debt crisis, the sum of all claims on the balance sheets of euro area NCBs stood very low, at around $100 € / \mathrm{b}$ prior to mid-2007 (ECB, 2015, pp. 42-43). They began to increase slowly after the blow up of the financial crisis in the United States in 2009 and, more rapidly, after the beginning of the public debt and banking crises in Europe in 2010, as documented by Fig. 3.

In Fig. 3, it is depicted the evolution of the sum of TARGET balances for the three NCBs (DE, LU, NL) with the largest claims (blue line), and the evolution of the three NCBs (IT, ES, PT) with the largest liabilities (yellow line). Note that the two lines pretty much mirror each other.

Following the European public debt crisis beginning in 2009, we can identify three different periods, corresponding to three different phases of the evolution of TARGET balances. 


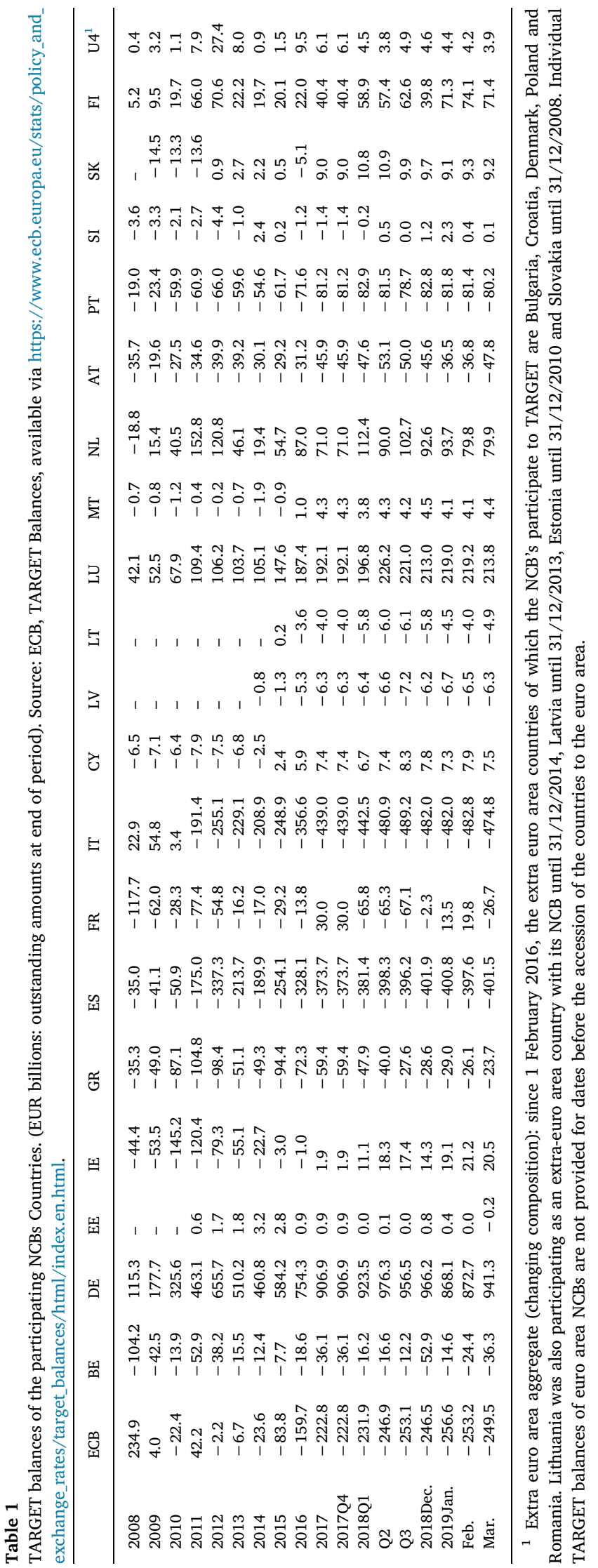




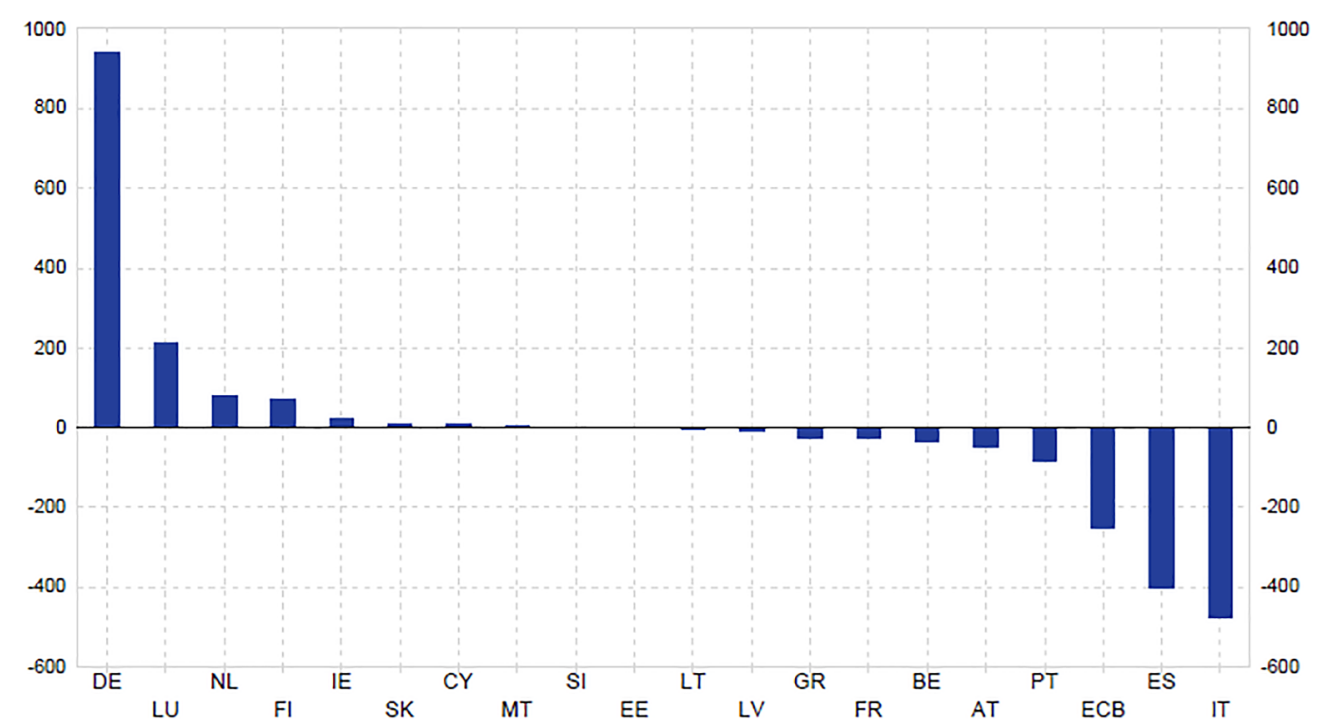

Fig. 1. TARGET balances at end March 2019. (EUR billions). Source: ECB, TARGET Balances, available via https://www.ecb.europa.eu/stats/ policy_and_exchange_rates/target_balances/html/index.en.html.

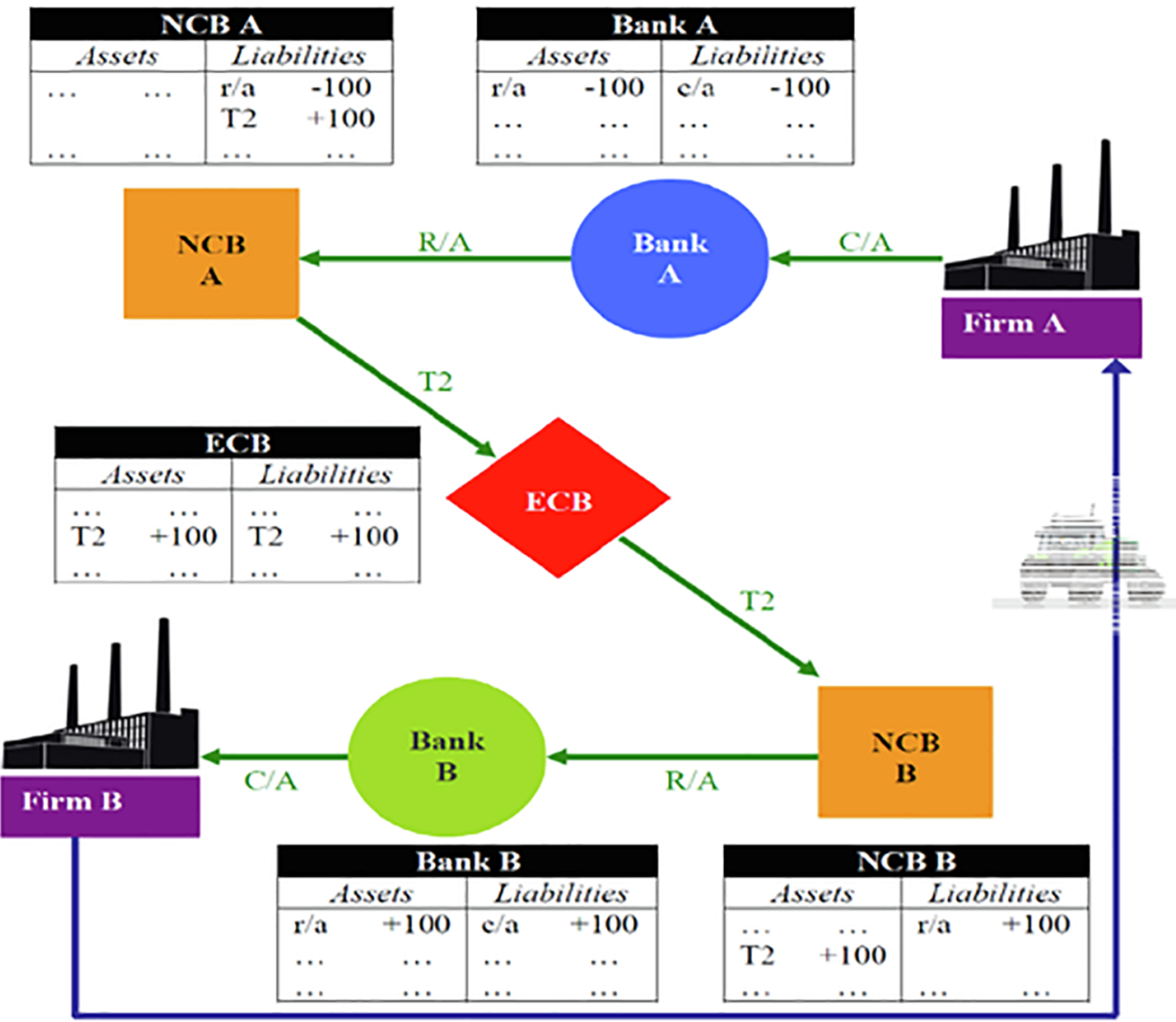

Fig. 2. Purchase of goods by firm A located in country A from firm B located in country B, both within the euro area. Source: Cecioni and Ferrero (2012).

The first period corresponds to the years of the public debt crisis, which begins in Greece in 2009 and culminates in mid-July 2012, when total TARGET credits of the three NCBs with the largest claims reached $1.000 € / \mathrm{b}$. The emergence of large TARGET imbalances during the crisis broadly reflected the distribution of non-cash central bank liquidity within the Eurosystem. This implemented its monetary policy in a decentralized manner, whereby the aggregate liquidity provision via the NCBs corresponded to 


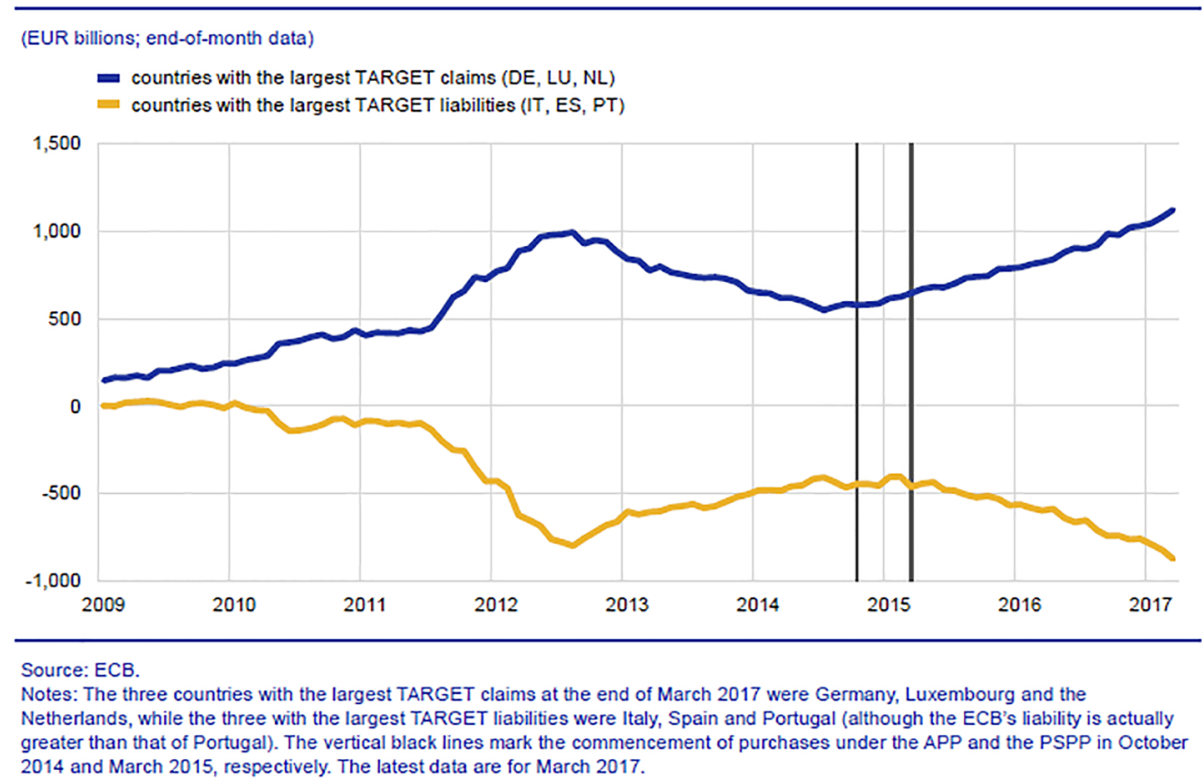

Fig. 3. Sum of TARGET balances for the three NCBs with the largest claims and the three with the largest liabilities. Source: ECB (2017b, p. 22).

the aggregate liquidity needs of the euro area banking sector.

Before the crisis, liquidity was regularly redistributed across banking sectors through the euro area interbank market. During the crisis, the liquidity needs of euro area banks increased significantly, with substantial dispersion across countries. At the same time, interbank markets dried up, which prevented the distribution of liquidity via private markets. ${ }^{3}$

Anyway, from the start of the crisis, the Eurosystem accommodated the euro area banking sector's liquidity needs, providing ample extra liquidity through its refinancing operations. As of October 2008, the Eurosystem has fully satisfied banks' demand for central bank liquidity in fixed-rate full-allotment (FRFA) tenders subject to the availability of eligible collateral. The significant increase in the recourse to central bank funding during the crisis, and its uneven distribution across countries, were associated with a corresponding rise in TARGET claims and liabilities. These increased until mid-2012 because of banks in some countries facing net payment outflows in conjunction with reduced access to short-term funding markets, while banks in other countries benefited from large financial inflows (ECB, 2015, p. 43).

The second period corresponds to decreasing TARGET imbalances in absolute value, which lasts for two years, exactly since July 2012 until July 2014. TARGET claims and liabilities stopped to increase after ECB's President, Mario Draghi, announced, at an investors' conference in London held in July 2012, that the ECB would have done "whatever it takes" to preserve the euro and fight the crisis.

Soon after this commitment, on September 6, 2012, the ECB approved the Outright Monetary Transactions (OMT) programme. Under this programme, the ECB promised to buy unlimited sovereign bonds of troubled countries in secondary markets, with a maturity of between one and three years. The program could be activated by the ECB only after an explicit request by the troubled country in which the latter agreed to accept the ECB's direct control and supervision of its financial and budgetary public policy. The purpose of this programme was, first, to reduce the spreads in the interest rates for public bonds of troubled countries with respect to German bonds, and, second, to safeguard the monetary policy transmission mechanism in all countries of the euro area, preserving the uniqueness of Eurozone monetary policy and ensuring the proper transmission of the policy stance to the real economy throughout the area (Altavilla \& Giannone, 2014).

As shown in Fig. 3, soon after Draghi's London speech, TARGET net positions stopped to increase and began to decrease towards lower levels. On December 2014, TARGET imbalances had fallen by half since July 2012 (Draghi, 2015), and this meant that confidence was again growing in the euro system.

TARGET claims and liabilities widened again in the second half 2014, which corresponds to the beginning of a third period of

\footnotetext{
${ }^{3}$ The crisis has not only had a strong impact on the financial situation of many European countries but has also affected investors' and lenders' confidence and the effectiveness of the financial sector. The tensions in sovereign debt markets and within the banking sector have fed each other, creating severe funding problems for many borrowers. These developments have also led to the fragmentation of the financial system along national borders, with a retrenchment of financial activities to national domestic markets. The resulting limited or costly access to funding for many businesses and households wishing to invest has been a major obstacle to recovery across Europe. At the same time, high levels of indebtedness mean that many economic actors must reduce their financial exposure or increase their savings. Such deleveraging could also hamper recovery in the short term. The problems were particularly acute in the vulnerable euro area member states (See Moro, 2016; Van Rixtel, 2013; Al-Eyd \& Berkman 2013; de Sola Perea \& van Nieuwenhuyze, 2014; European Commission, 2013).
} 
newly increasing TARGET imbalances. This in part reflected the relatively higher participation of banks in some countries with TARGET liabilities in the Targeted Longer-Term Refinancing Operations (T-LTROs) program launched in June 2014, as these operations tended to be more attractive for such counterparties. Furthermore, the expanded asset purchase programme (EAPP), usually known as the first quantitative easing (Qe1) programme, that started in March 2015, affected TARGET balances when the buying and selling parties are operating in different jurisdictions, which might explain more recent developments.

Anyway, interpreting TARGET balances within an integrated financial system like the euro area requires caution. For instance, these imbalances also reflect money transfers within large, cross-border banking groups, where the central bank money (CBM) needed by the group is procured centrally at one NCB and then redistributed among group members via TARGET. These imbalances also reflect payment flows caused by remote participants. Other factors that highlight the need for caution include differing preferences between euro area countries regarding holding banknotes and access to the Eurosystem monetary policy instruments of banks outside the European economic area, via subsidiaries in a country connected to TARGET. Finally, cross-country purchases of securities in the context of the EAPP may affect TARGET balances but do not indicate financial stress. Thus, TARGET balances do not, and are not meant, to provide a complete picture of the net financial flows between countries (ECB, 2011, pp. 38-39, 2015, p. 44).

\section{The accumulation of TARGET imbalances during the crisis}

The emergence of large TARGET imbalances during the crisis broadly reflected the distribution of non-cash central bank liquidity within the Eurosystem. The Eurosystem implements its monetary policy in a decentralized manner, whereby the aggregate Eurosystem liquidity provision via its NCBs corresponds to the aggregate liquidity needs of the euro area banking sector. Liquidity can be redistributed across banking sectors through the euro area interbank market.

During the crisis, the liquidity needs of euro area banks increased significantly, with substantial dispersion across countries. At the same time, interbank markets dried up, which prevented the distribution of liquidity via private markets. From the start of the crisis, the Eurosystem accommodated the euro area banking sector's liquidity needs, providing ample extra liquidity through its refinancing operations (ECB, 2015, p. 43).

TARGET imbalances are closely correlated to countries' recourse to Eurosystem refinancing operations through the NCB balance sheets, but they are not caused by these operations. The conventional monetary policy instruments, through which the Eurosystem provides central bank money, are the main refinancing operations (MROs), the longer-term refinancing operations (LTROs), and the marginal lending facility (ML). During the crisis, a regime of fixed-rate and full allotment (FRFA) procedure has been adopted for all refinancing operations, eligibility criteria for collateral have been widened, and the maximum maturity of the LTROs has been progressively increased.

Moreover, unconventional tools - the Covered Bonds Purchase Programmes (CBPP1, CBPP2) and the Securities Market Programme (SMP) - were introduced to counter market impairments and to preserve the functioning of the monetary policy transmission mechanism. These exceptional measures determined a strong expansion of the Eurosystem's balance sheet. To show that, it is important to explain how the circulation of central bank money (CBM) occurs in the Eurosystem. Therefore, let us indicate with OMO (open market operations) the liquidity provided through MROs, LTROs, ML, SMP and CBPPs, net of the liquidity absorbed through fixed term deposits. Fig. 4 shows how the circulation of CBM between countries with positive TARGET balances and countries with negative balances occurred before and during the crisis. Without loss of generality, we consider only two countries (Germany for the first group of countries, and Greece for the second one), we assume that the net autonomous factors are zero in both countries, that the two banking sectors have the same size and that during the crisis the German banks' recourse to OMOs is zero.

Quoting Cecioni and Ferrero, «before the crisis (panel A), both banking sectors obtain $€ 1$ from their respective NCB in OMOs (blue arrow), deposit it in their reserve account, use their respective NCBs to settle payments through TARGET with the banking sector of the other country (red and green arrows 1, 2, 3 and 4) and use the reserves obtained through TARGET to satisfy the reserve requirement (red and green arrows 5). In particular, the reserves used by the German banking sector to settle payments to Greece through TARGET ( $€ 1$ ) gives rise to the following flows between the banks of the two countries, the respective NCBs and the ECB: (i) the German banks reduce by $€ 1$ their reserve account with the Bundesbank (red arrow 1), which, in turn, records a TARGET liability towards the ECB of the same amount (red arrow 2); (ii) conversely, the Bank of Greece records a $€ 1$ TARGET claim (red arrow 3 ) and transfers the same amount to the Greek banks reserve account (red arrow 4); (iii) the Greek banks use the $€ 1$ to satisfy their reserve requirement (red arrow 5); at the same time, the Greek banks use the reserve obtained in the OMO to settle transactions with their German counterparts, again involving the respective NCBs and the ECB as central counterpart (green arrows 1, 2, 3 and 4); the German banks use the reserves obtained through TARGET to satisfy their reserve requirement (green arrow 5). At the end of the day, the flows on TARGET are balanced and no excess reserves are held either by Greek or German banks» (Cecioni \& Ferrero, 2012, pp. 12-13).

Going on quoting, «with the outbreak of the crisis (panel B), the German banks scale back their transactions with their Greek counterparts. Reduction in the velocity of circulation needs to be compensated with an increase in quantities of money; this is what the ECB has been doing with the changes in the Eurosystem OMOs procedure (introduction of FRFA and enlargement of the eligible collateral). It allowed the Greek banks to increase their demand for funds in OMOs to €3 (blue arrow) and to use this liquidity to satisfy their reserve requirements ( $€ 1$; orange arrow) and for payments to the German banking sector through TARGET ( $€ 2$; green arrows 1, 2, 3 and 4). The German banks satisfy their reserve requirements ( $€ 1$ ) with the funds received through TARGET ( $€ 2$; green arrow 5) and keep the additional liquidity ( $€ 1$ ) as excess reserves in the deposit facility or in term deposits (violet arrow). The Bank of Greece and the Bundesbank display, respectively, a debit and a credit position of $€ 2$ on TARGET towards the ECB» (Cecioni \& Ferrero, 2012, p. 13). 


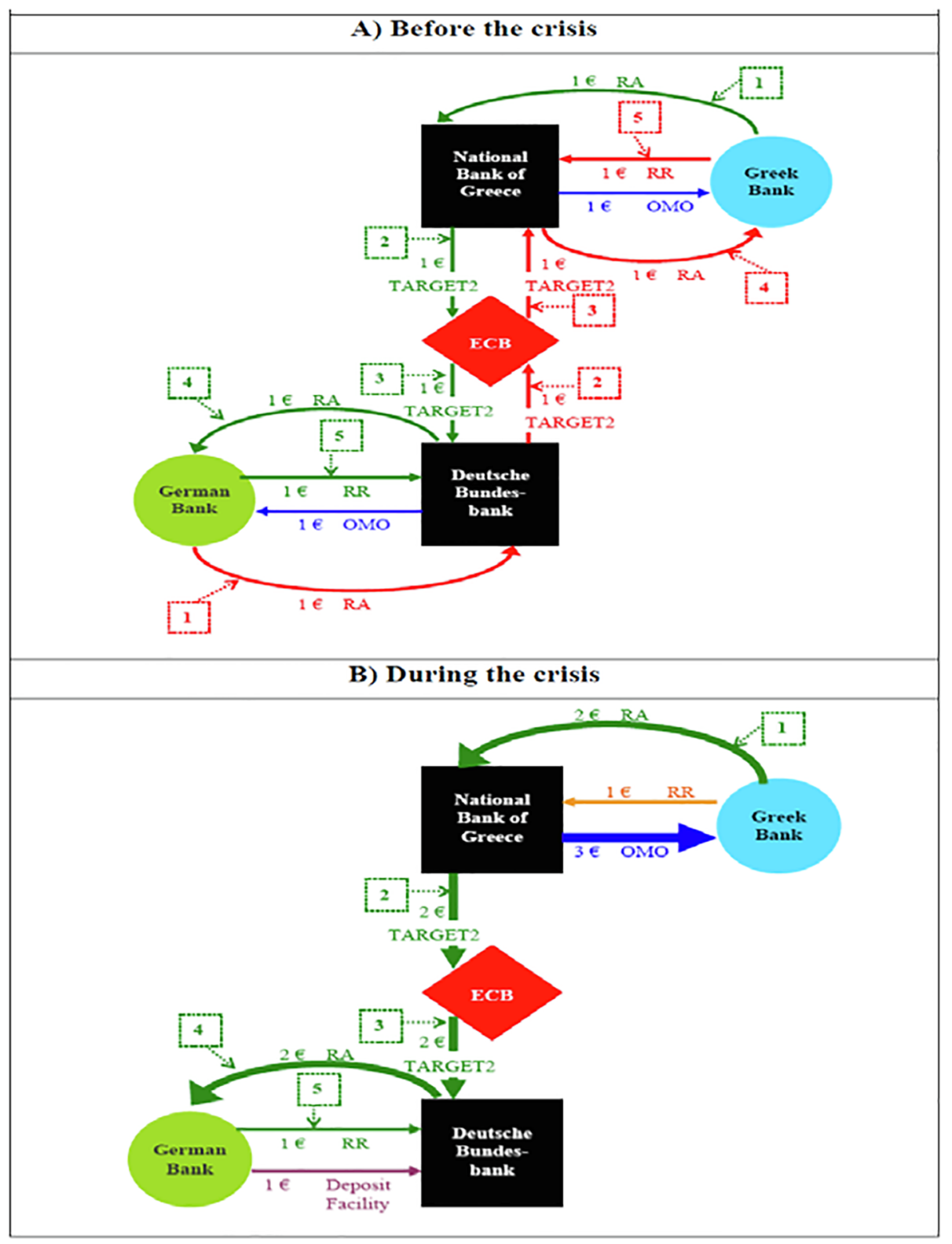

Fig. 4. The circulation of central bank money. Source: Cecioni-Ferrero (2012).

Three aspects need to be stressed regarding NCB balance sheets and the circulation of central bank reserves before and during the crisis. First, the changes in the circulation of central bank reserves observed during the crisis between banks of different nationality would have been observed also outside a monetary union, in an economy populated by "good" banks, with liquidity constraints not binding, and "bad" banks, with no access to wholesale markets. Also, in this case the recourse of bad banks to refinancing operations would have increased, and unidirectional flows of reserves from the bad to the good banks would have occurred. In the Euro area this phenomenon is involving the banking sectors of specific countries as tensions originated in the sovereign debt market are transmitted rapidly to the banking sector. Second, the decision to adopt the FRFA procedure in refinancing operations and to enlarge the eligibility criteria for the collateral compensated for the reduction in velocity of circulation of CBM. The rise of liquidity and the widening of the TARGET balances reflect the financial market tensions. These unconventional measures have been necessary to counter the pressures on banks' liquidity and on financial markets caused by the massive disruption of interbank and capital markets at the peak of the crisis, which was undermining the functioning of the payment system and the uniform and smooth transmission of monetary policy. Third, in countries not exposed to financial market tensions the reduced recourse to Eurosystem's refinancing operations reflected a smaller need for liquidity, because of the larger net inflows of CBM from the crisis-hit countries. The fact that in some countries banks have substituted reserves obtained directly in OMOs with those obtained through TARGET has no consequences on their ability to finance the economy (Cecioni \& Ferrero, 2012, p. 13). 


\section{The critics to TARGET imbalances during the crisis}

There is a field of research that criticizes the managing of TARGET balances by the ECB during the European public debt financial crisis. According to Sinn (2011, 2012a, 2012b) and Sinn and Wollmershäuser (2011, 2012), «by reducing the collateral requirements for the refinancing credits of Eurozone central banks, the ECB undercut market rates in the southern Eurozone countries. This enabled a huge asymmetric expansion of refinancing credit and money creation, compensating for stalling capital imports and outright capital flight» (Sinn 2012b, p. 1). ${ }^{4}$

«The monetary expansion in the southern countries in turn enabled a net outflow of central bank money to other Eurozone countries by way of international payment orders for the purpose of buying goods and assets and redeeming foreign debt» (Sinn 2012b, p. 1). Sinn (2012b) and Sinn and Wollmershäuser (2012) claim that this outflow is a classical balance of payments imbalance, and that its accumulated value is measured by the TARGET balances.

«In the surplus countries, commercial banks placed the funds they withdrew from the deficit countries in the deposit facility of their own central banks, which implied a sterilization of the inflowing liquidity. Because of this sterilization, the policy has not been inflationary, but for that same reason it can be considered as a pure fiscal credit transfer (a "stealth bailout") that resembles the official intergovernmental credit transfers» (Sinn, 2012b, p. 2).

Sinn and Wollmershäuser (2012) also argue that this policy was defensible at the time of the Lehman crisis, but has meanwhile begun to undermine the allocative function of the capital market by offering credit at conditions that do not take idiosyncratic country risks into account and undercut the market rates. They also maintain that the TARGET debts imposed risks on the rest of the Eurozone countries in proportion to their share in the ECB capital, should the deficit countries default and leave the Eurozone. In the case of a breakup of the Eurozone, the surplus countries' TARGET claims themselves would be at risk. They note, moreover, that «saying that the current-account deficits were sustained with the extra refinancing credit behind the TARGET balances does not equate to claiming that current account deficits and TARGET deficits were positively correlated. On the contrary, to the extent that the ECB helped slow down the adjustment of pre-crisis current account deficits despite the reversal of private capital flows, the correlation should have been small if not zero, while the correlation between private capital imports and TARGET deficits was strongly negative. This means that the ECB's extra refinancing credit, which resulted in TARGET debt, helped provide the funds needed to finance the current account deficits» (Sinn 2012b, p. 2, and Sinn \& Wollmershäuser, 2012).

This conclusion, according to Sinn and Wollmershäuser, is confirmed by the definition of a country's budget constraint, according to which the sum of TARGET balances, private and intergovernmental international capital flows, and current account imbalances is zero. The policy implication of this interpretation of TARGET balances is that, when exchange rate adjustments are impossible, the accumulation of credit and debit positions in TARGET balances needs to be limited and imbalances of cross-border payment flows must be accommodated officially on an annual basis (Sinn \& Wollmershäuser, 2012; Moro, 2016, p. 110).

These arguments were rebutted by many authors (Whelan, 2011, 2012; Buiter \& Rahbari, 2011; Buiter \& Rahbari, 2012; Bindseil \& König, 2011; Cecioni \& Ferrero, 2012; Deutsche Bundesbank, 2011; ECB, 2011; and Banca d'Italia, 2012), whose main conclusions can be summarized as follows. The fact that for some banking systems, such as Germany's, the refinancing obtained from the Eurosystem, net of the funds placed with the reserve account and the deposit facility, is negative in no way limits the ability of the Eurosystem to control the monetary base. What is important for the transmission of monetary policy is the net liquidity provided to euro-area banks, not how it is distributed. More generally, the increase of TARGET imbalances does not interfere with the conduct of monetary policy or the objective of price stability within the area. In particular, the existence of a large positive TARGET balance in some euro-area countries does not entail a risk of inflation. The Eurosystem maintains its ability to mop up all the excess liquidity with appropriate instruments whenever changes in economic and financial conditions make this necessary (Cecioni \& Ferrero, 2012, pp. 7-9; Moro, 2016, p. 110).

Moreover, in the Eurosystem the increase of TARGET imbalances does not create any specific risk not already contained in monetary policy refinancing operations, which in any case for the NCBs is managed and mitigated by the threshold for the quality of collateral accepted in refinancing operations and the system of haircuts. Also, it is shared across the Eurosystem according to the ECB's capital key and thus independent of the credit or debit TARGET position of each single NCB (Cecioni \& Ferrero, 2012, pp. 8; Moro, 2016, p. 111).

All Eurosystem credit is given to counterparties only against eligible collateral, to protect the central bank against losses arising from the potential default of a counterparty. In principle, the list of eligible collateral is uniform throughout the euro area and encompasses a wide range of assets. The value of collateral posted by counterparties is calculated daily and haircuts are applied to safeguard against possible liquidation losses should a counterparty default. These measures are important elements of the Eurosystem's risk control framework (ECB, 2013, p. 111). ${ }^{5}$

\footnotetext{
${ }^{4}$ For a comment on this argument, see Cecioni and Ferrero (2012) and Moro (2014, 2016).

${ }^{5}$ In the event of a counterparty's default on an obligation arising from Eurosystem credit operations, the collateral is seized and sold in the market to mitigate potential losses. In general, if the anticipated cash receipts linked to the collateral are insufficient to cover the counterparty's obligation, then at the time of the default each euro area NCB records a provision equal to its share in the total amount of that expected loss. This share is determined according to the capital key prevailing at the time of the default. These provisions are reviewed and adjusted accordingly at the end of each financial year by the Governing Council of the ECB. An exception to this Eurosystem risk-sharing practice is the framework for Emergency Liquidity Assistance (ELA). ELA aims to provide central bank money to solvent financial institutions that are facing temporary liquidity problems, outside of normal Eurosystem monetary policy operations. The rules and procedures surrounding the provision of ELA are laid down in the ELA agreement, which sets out the Governing Council's role in the provision of ELA by national central banks (NCBs), in particular when assessing,
} 
In conclusion, considering the mechanics of the transactions and the economic factors behind these imbalances, and looking at balance of payments (BOP) identities, we can argue that «TARGET imbalances are correlated to the recourse to monetary policy refinancing operations, via NCBs' balance sheets, but they are not caused by them. Adopting the fixed-rate full allotment (FRFA) procedure in the refinancing operations and expanding the list of eligible collateral countered the pressures on banks' liquidity and on financial markets, which originated from the massive disruption of interbank and capital markets at the peak of the crisis and to the drying up of cross-country flows. These measures played a key role in preserving the functioning of the payment system and the financial stability of the euro area» (Cecioni \& Ferrero, 2012, p.8), with the implication that the resulting increase in central bank's reserves was accompanied by the widening of TARGET imbalances (Moro, 2016, p. 111).

\section{The link of TARGET balances with the balance of payments}

The increase in TARGET imbalances has been closely linked to balance of payments (BOP) imbalances. During the crisis, trade balance deficits were neither necessary nor enough conditions for the increase in TARGET imbalances. BOP financial account imbalances, instead, were a necessary condition. ${ }^{6}$ Before the crisis, both the BOP current account and the trade balance of the countries under stress were in deficit, except for Italy where they were approximately balanced. These deficits were funded mostly from foreign investments in domestic securities and in the interbank market. The capital flowing in and out of the countries was almost completely netted out, leaving small average net balances for the individual items of the BOP financial account (Cecioni \& Ferrero, 2012, p.16).

It is important to remember that, inside the EMU, an increase in TARGET balances for a member country is equivalent to an increase in foreign reserves, while a decrease is like a reduction of foreign reserves. For instance, a capital flight to abroad determines a reduction of TARGET balances (which means a smaller credit position or a greater debt position of the involved NCB with respect to the ECB), instead of a reduction in foreign reserves. This means that any movement in TARGET balances changes the net foreign position of the country.

During the crisis, «the absolute size of individual items in the EMU countries' BOP increased and its composition changed significantly. The main changes were in the financial accounts. In crisis-hit countries, the reversals of foreign investments in domestic securities and of liabilities issued by domestic monetary and financial institutions (MFIs) were not matched by a similar increase in disinvestments of domestic capital previously invested abroad» (Cecioni \& Ferrero, 2012, p. 8). ${ }^{7}$ As a consequence, net outflows in the financial accounts of the BOP were compensated by a considerable increase in the respective NCB's TARGET liabilities with the ECB.

The timing of these changes was uneven across countries. «During the global financial crisis (August 2007-April 2010) and in the first phase of the sovereign debt crisis (May 2010-June 2011), Italy's and Spain's financial accounts remained almost unchanged while those of Greece and Portugal showed the largest adjustments. In the latter countries, foreigners disinvested from the interbank and the securities markets, and some signs of deposit flight from domestic banks by residents appeared. In the second phase of the sovereign debt crisis (July 2011-May 2012), access to international financial markets by the Italian and Spanish governments and MFIs was also impaired. During this period, Italy and Spain recorded net outflows from the MFIs, respectively, of 118 and $182 € / \mathrm{b}$, and net outflows of portfolio investments. In Italy, in particular, net outflows of portfolio investments largely corresponded to a willingness in non-residents not to roll over maturing sovereign debt securities and, to a lesser extent, to sales by non-residents of sovereign debt securities on the secondary market» (Cecioni \& Ferrero, 2012, pp. 18-19).

Correspondingly, at the end of 2012, TARGET liabilities increased for Italy and Spain to $-255.1 € / \mathrm{b}$ and $-337.3 € / \mathrm{b}$, respectively (see Table 1). As to the implications for the monetary policy transmission and the risks for the balance sheet of the Eurosystem, the main conclusion was that the ECB's unconventional monetary policies contrasted the risks of segmentation in the money markets along national borders with the aim of preserving the transmission of the unique monetary policy. "Any institutional change that would limit the flow of payments through TARGET would have a pro-cyclical effect, by tightening further liquidity conditions in troubled countries, and it would increase asymmetries within the euro area, undermining the existence of the unique monetary policy. Furthermore, when evaluating the cross-country risks, it should be considered that member states' net external positions had not changed because of the widening of TARGET balances. Rather, private credit (debit) positions had been substituted by NCBs' credit (debit) TARGET positions vis-à-vis the ECB. Therefore, the risks that before the crisis were entirely borne on the private sector of creditor countries after the crisis were mainly shared across Euro system's NCBs» (Cecioni \& Ferrero, 2012, pp. 18-19). ${ }^{8}$

\footnotetext{
(footnote continued)

pursuant to Article 14.4 of the Statute of the European System of Central Banks (ESCB) and of the ECB, whether the provision of ELA by Eurosystem NCBs interferes with the objectives and tasks of the ESCB. The use of ELA by counterparties is subject to comprehensive and regular evaluation by the Governing Council of the ECB and is only available for solvent institutions (ECB, 2013, p. 111). On the emergency liquidity assistance (ELA) and monetary policy, see also on the website of the ECB https://www.ecb.europa.eu/mopo/ela/html/index.en.html.

${ }^{6}$ On this argument see Cecioni and Ferrero (2012, p. 15-19) and Moro (2016).

${ }^{7}$ In fact, what happened in the periphery countries was a twin crisis as described in Kaminsky and Reinhart (1999), as the financial crisis stopped the capital inflows ('sudden stop'), producing both a banking crisis (as banks could not be financed, here the causality is double, as the bad performance of banks is also responsible for the stop in inflows) and a current account crisis (as the capital inflows helped to finance the current account).

${ }^{8}$ Auer (2014) examines the extent to which changes in national TARGET balances can be statistically associated with cross-border private capital flows and current account (CA) balances. His first conclusion from this analysis is that since TARGET imbalances were caused by a sudden stop and were unlikely to grow without bounds, as Eurozone CA imbalances were currently diminishing at a rapid pace, there was no evidence that the institutional set-up of the European monetary union needed to be reformed fundamentally. A further conclusion relates to how the current system
} 
Nevertheless, in general the banking system cannot permanently rely on central bank funds for its main source of funding. In the medium term, peripheral countries cannot continue to substitute inflows of foreign private sector liquidity with TARGET liabilities. Stressed countries must return to private markets and attract funds from the rest of the area. This required the restoration of confidence in both the banking sector and in the sustainability of public finance.

Similar conclusions are reached by Whelan (2012, 2014), who first argued that the process by which TARGET liabilities were incurred does not change the net asset positions of central banks, because they either replace existing liabilities or the latter are combined with the addition of new assets. According to Whelan, rather than an external bailout, in practice the increase in TARGET balances reflected the ability of national central banks in the Eurosystem to create money to lend to banks experiencing funding problems and so, if anything, these balances reflected countries "bailing out themselves". Whelan agreed that the large changes in intra-Eurosystem balances during the crisis were the result of capital flight from the periphery rather than the accumulation of current account deficits.

These balances had evolved due to the monetary policy strategy agreed by the ECB's Governing Council and because of the free movement of capital guaranteed by the EU rather than because of any special features of the TARGET payments system. Indeed, he described how large changes in intra-Eurosystem balances would have occurred due to capital flight even if electronic bank transfers via TARGET had been shut down and only cash payments allowed.

The increasing risks for Germany associated with the Bundesbank's TARGET balances had been offset to a large extent by a significant decline in private German bank exposures to the periphery. Therefore, also in the extreme event of a full uncooperative euro breakup, Whelan argued that the underlying costs to German taxpayers would have been far lower than the regularly cited full value of the TARGET balances. ${ }^{9}$

Finally, Whelan argued that the Eurosystem should consider proposals for annual settlement of TARGET balances, with settlement taking place using assets acquired during monetary policy operations, or state-owned real estate. Such a settlement procedure would see TARGET balances reset to zero each year, which is a procedure somewhat like the annual liquidation of the 12 Federal Reserve districts balances in the US. For Whelan, while this proposal would imply a change in the Eurosystem's accounting procedures for dealing with balances owed between its members, it would not change the daily operations of the TARGET payments system nor would it change the nature of risk-sharing on monetary policy operations in place for euro member States.

On this conclusion, we strongly disagree. The problem is that, in practice, both Sinn's proposal, discussed in the previous Section 4, and Whelan's proposal, discussed in this section, are not viable. While Sinn (2011) suggestions to limit TARGET balances would imply an effective end to the euro as a common currency, also Whelan's proposals for annual settlement of TARGET balances using assets acquired during monetary policy operations, or state-owned real estate, or senior rights to future tax revenue (Sinn, 2012a), would represent a significant change to current risk-sharing arrangements, in relation to monetary policy operations and therefore would undermine the working of a common monetary policy (ECB, 2013; Bindseil, 2011; Cecioni \& Ferrero, 2012). Therefore, neither of these proposals are consistent with a continuation of the euro as a common currency.

In fact, the TARGET balances of euro area NCBs reflect the uneven distribution of central bank money (CBM), or liquidity, within the Eurosystem. As there can be no upper limit on the value of payment flows within a single currency area, there can be no upper limit on the TARGET balances of NCBs. Limiting the size of TARGET balances would be inconsistent with the concept of a currency union.

Similarly, in the United States, there are no limits on payment flows within the currency area formed by the 12 Federal Reserve districts. Interdistrict balances emerge from such payment flows, which are not more constraining than the TARGET balances are in the Eurosystem. The mechanism used in the United States to readjust interdistrict balances once a year has no influence on crossborder payment flows and essentially leads to the adjustment of the key used for the allocation of profits and losses of the US Federal Reserve System to the 12 district Reserve Banks (ECB, 2013, pp. 112-14). ${ }^{10}$

To conclude on this point, it is important to stress further that in the EMU a claim in TARGET does not reflect the relevant NCB's exposure to financial risk. The risk exposure of the central banks forming the Eurosystem relates to the monetary policy operations themselves, not to the associated TARGET balances. In general, we know that a central bank faces counterparty risk when implementing monetary policy, and the risk associated with the provision of central bank liquidity as part of the implementation of monetary policy is mitigated by a risk management framework. ${ }^{11}$ Therefore, as long as the EMU is regularly functioning and

\footnotetext{
(footnote continued)

transfers risks across the currency union. Limiting or settling TARGET balances are not viable options. Rather, policies must be geared to limiting the implicit risk transfer from the private to the public sector within TARGET creditor nations, which is facilitated by the current system as it may change the incidence of euro break-up risk.

${ }^{9}$ This is partly because the rest of the Eurosystem had a large claim of about $€ 200$ billion on Germany, relating to banknote issuance, and partly because the seigniorage powers of a post-breakup for the Bundesbank were likely to be considerably high. Whelan's conclusion is shared by De Grauwe (2012) who argued that, also in the extreme case of a euro break up, the risk of losing TARGET claims for surplus countries did not exist. A similar interpretation is also given by Buiter and Rahbari (2012).

${ }^{10}$ Because of payment flows between the Federal Reserve districts, surpluses or deficits naturally emerge in interdistrict balances. These balances enter the Interdistrict Settlement Accounts, which are settled once a year, in April. The annual settlement is based on each Reserve Bank's average interdistrict balance during the preceding 12 months (April to March), so that it does not generally bring the balances back to zero. The settlement mainly consists in adjusting the relative shares of the 12 Reserve Banks in the securities holdings in the Open Market Account of the Federal Reserve System (ECB, 2011, p. 39).

${ }^{11}$ The Eurosystem's collateral framework is based on a public list of securities fulfilling the relevant eligibility criteria, together with risk control
} 
considering the irreversibility of the euro, we can conclude on this point that, for a regular and fair working of the EMU, it is not necessary an annual liquidation of TARGET balances from debit to credit countries.

\section{The accumulation of TARGET imbalances during the Qe period}

The crisis has caused significant disruptions to the functioning of the European banking systems and the financial markets. The process of integration and convergence towards a single financial market was halted, triggering a reversal of the integration process, which was then reinforced by the re-emergence of country risks within the euro area and by the related and perverse bank-sovereign feedback loop.

To contrast these new phenomena, European leaders agreed during the 29 June 2012 summit to build a banking union that would include a single banking supervisor housed within the ECB, a common deposit insurance for households and a common bank resolution rule. However, the lack of progress on the banking union and doubts about the financial strength of the banks in crisis-hit countries were hindering cross-border lending. So, the fragmentation of the financial system along national borders and the retrenchment of financial activities to national domestic markets persisted during 2013 and the first half of $2014 .^{12}$ Therefore, to contrast the crisis, in the second half of 2014 the ECB decided to promote a quantitative easing (Qe) monetary policy. Because of this decision, beginning on July 2014, TARGET net claims and liabilities stopped to converge and began to diverge again (see Fig. 3).

Anyway, these new divergences were not correlated with imbalances in the foreign current accounts. What was really happening since the midst of 2014 was very different from what happened in 2012 and did not reflect a "flight to safety" as it did back then. In fact, the new divergence was a consequence of the announced ECB's asset purchase program (APP), usually known as the quantitative easing (Qe) program, which was announced in June 2014, as well as of the following current very low levels of policy interest rates set by the ECB. For the first time in the euro area one of the ECB's key policy interest rates was set negative. ${ }^{13}$

This set of unconventional monetary policy measures is commonly known as the first phase of ECB's quantitative easing monetary policy (Qe1). On March 2015, the Eurosystem expanded its existing purchase programmes for asset-backed securities (ABSPP) and covered bonds (CBPP3), that had been up and running since the autumn of 2014, through the addition of a public-sector purchase programme (PSPP). The purpose of this new programme was to purchase bonds issued by euro-area central governments as well as by agencies and supranational European institutions. The total purchase volume of the expanded asset purchase programme (EAPP) amounted to roughly $60 € / \mathrm{b}$ per month in 2015, with the PSPP thus far accounting for the bulk of acquisitions at around $85 \%$ of this total.

Further, on March 2016, the ECB started a second phase of quantitative easing (Qe2). The interest rate on the MROs of the Eurosystem was decreased to zero, while the interest rate on the marginal lending facility was decreased to $0.25 \%$, and the interest rate on the deposit facility, after an intermediate decrease to $-0.3 \%$ in October 2015 , was decreased to $-0.4 \%$. The monthly purchases under the EAPP was increased from 60 to $80 € / \mathrm{b}$, and investment grade euro-denominated bonds issued by non-bank corporations established in the euro area were included in the list of assets that were eligible for regular purchases.

A new series of four targeted long-term refinancing operations (T-LTRO II), each with a maturity of four years, was launched, starting in June 2016. Borrowing conditions in these operations could be as low as the interest rate on the deposit facility ( $-0.4 \%)$, which meant that banks who borrowed from the ECB to finance new investments of firms received a premium of $0.4 \%$ instead of paying an interest rate. ${ }^{14}$

At the December 2016 meeting, the ECB's Governing Council decided to strengthen the convergence of inflation rates towards $2 \%$ over the medium term. For this to happen, financing conditions would have to remain supportive. Therefore, the ECB decided to safeguard the amount of monetary easing for the period ahead, and to extend the asset purchase programme beyond March 2017, with the intention of conducting purchases until the end of December 2017 or beyond, if necessary.

The ECB continued to purchase assets at a monthly pace of $80 € / \mathrm{b}$ until March 2017. Starting from April 2017, the net asset purchases dropped again to a monthly pace of $60 € / \mathrm{b}$, further reduced to $30 € / \mathrm{b}$ in January 2018. Anyway, in June 2017 , the ECB decided to maintain unchanged interest rates on MROs (0\%), marginal lending facility (0.25\%) and deposit facility ( $-0.4 \%)$ even after the conclusion of the EAPP. Therefore, central bank money (CBM) provision via the various purchase programmes has very much elevated the amount of excess liquidity in the Eurosystem, as it is depicted in Fig. 5.

Finally, at the March 2018 meeting, the ECB's Governing Council decided to go on buying $30 € / b$ monthly at least until September 2018, and to maintain unchanged official key interest rates at the levels mentioned above, if necessary for a long time even after that

\footnotetext{
(footnote continued)

measures. Securities pledged as collateral are valued daily, at market prices (where available) or using conservative valuation methods, with haircuts also being applied. The residual risk associated with the provision of central bank liquidity that may emerge despite the risk mitigation measures is, as a rule, shared among the NCBs of the Eurosystem in accordance with their respective shares in the ECB's capital and is not related to the TARGET positions of individual central banks (ECB, 2011, pp. 39-40).

${ }^{12}$ The financial crisis also led to a systematic divergence in credit spreads for financial firms across national boundaries. This divergence in crosscountry credit risk increased further as the European debt crisis has unfolded since 2010. Since that time, credit spreads for both non-financial and financial firms increasingly reflected national rather than euro area financial conditions (Gilchrist \& Mojon 2014).

${ }^{13}$ The interest rate on the MROs was fixed at $0.05 \%$, while the interest rates on the marginal rate facility and the deposit facility were fixed at $0.3 \%$ and $-0.2 \%$, respectively. On the implications of setting one of the ECB's key policy rates to negative territory, see Demiralp et al (2017).

${ }^{14}$ Alvarez et al. (2017) provide a comprehensive overview of the use of the Eurosystem's monetary policy instruments and the operational framework from the third quarter of 2012 until the first quarter of 2016.
} 


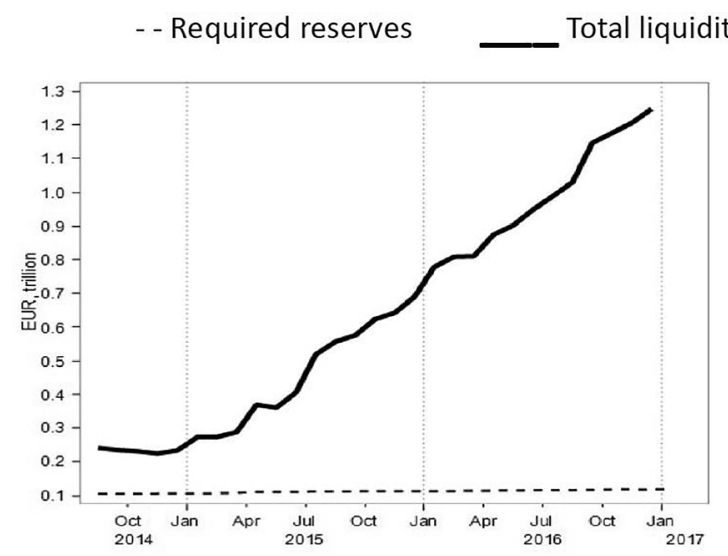

Fig. 5. Banking liquidity created by Qe programs. Source: ECB.

date. Since October 2018, the purchases have been reduced to 15 billion, until the end of December 2018, when net purchases ended. After that date, the ECB stays engaged to reinvest only the value of bonds reimbursed on maturity. Anyway, the ECB's key interest rates mentioned above will remain unchanged at least through the summer of $2019 .{ }^{15}$

At the same time, since the last months of 2016 the total sum of TARGET claims and liabilities in the Eurosystem has sharply risen again up to the levels reached on mid-2012 during the more acute phase of the financial crisis (see Fig. 3). Anyway, in contrast to previous periods of rising TARGET balances, changes in the TARGET balances immediately after EAPP purchases are a direct consequence of the implementation of the above mentioned unconventional monetary policy decisions, rather than a symptom of renewed stress in financial markets.

The increases in TARGET imbalances from mid-2011 to mid-2012 were rooted in the market stress and fragmentation that resulted from the financial and sovereign debt crises. As banks lost access to market-based funding, they replaced private sources of funding with central bank liquidity obtained from their NCBs through repurchase operations. Those repurchase operations had no immediate impact on TARGET balances, as they were settled domestically, but the subsequent redistribution of liquidity, influenced by market stress and fragmentation, did have an impact. The link between the implementation of monetary policy decisions and TARGET balances was therefore indirect.

With the EAPP, however, there is a direct link, since central banks are initiating cross-border payments to pay for securities purchased under the various programmes. The ensuing upward trend in TARGET imbalances largely reflected the settlement of these cross-border transactions by central banks and, therefore, did not signal renewed stress in financial markets (ECB, 2016, pp. 3-4). It is therefore reasonable to assume that the recorded increase in the TARGET imbalances in this more recent period related to the ECB's quantitative easing policy correlated to the EAPP (ECB, 2016, pp. 3-4; Eisenschmidt et al., 2017).

There are some technical reasons why this is so. In fact, almost $80 \%$ of the bonds that were being purchased by NCBs within the EAPP were sold by parties that did not reside in the same place as the purchasing NCB, and roughly half of them accessed the TARGET system via the Bundesbank. The bulk of the sellers of bonds to the NCBs were clients of German banks, or banks in non-euro countries that were using German banks as correspondent banks. ${ }^{16}$

So, German banks settled the bonds for their clients, credited the account of their clients, and their liquidity balance went up. Because liquidity was more than those banks needed, most of them had no borrowing needs, and any excess liquidity was hardly loaned to other banks (Martínez Pagés, 2016). Under conditions of ample liquidity, those few banks that needed liquidity had two options: 1) borrow in the interbank overnight market for liquidity, where the interest rate was negative, or 2) borrow at weekly ECB auctions at $0 \%$ interest rate.

What happened was that banks in the "periphery" would only be willing to borrow from German banks with ample liquidity at a cost that was negative. Banks in the "core", however, still perceived a counterparty risk on banks in the periphery, although much less dramatic than in 2011-12. And as long as their lending premium was high enough to make borrowing from the Eurosystem a more

\footnotetext{
${ }^{15}$ The quantitative final summary of the six programmes contained in the EAPP, with the reinvestment phase of the whole asset purchase programme, is illustrated in ECB (2019).

${ }^{16}$ See Deutsche Bundesbank (2016, pp. 53-56), Eisenschmidt et al (2017), and Terzi (2015). According to Mario Draghi, «it is true that TARGET balances have gone up, but they started going up since the beginning of our asset purchase programme, and there are some technical reasons why this is so, namely almost $80 \%$ of the bonds that are being purchased by national central banks within this programme are sold by parties that do not reside in the same place as the purchasing national central bank, and roughly half of them accessed the TARGET system via the Bundesbank. And so naturally you see TARGET balances going up in Germany. But there is also another reason, namely that the purchasing of assets induces portfolio rebalancing effects on the part of the sellers of these assets, and in recent times, some of them have sold bonds and are buying other securities, not the domestic securities but other securities, or other forms of investment. So, we see the TARGET balances going up, but I would not say that this has something to do with the experience we had in 2012. The two phenomena are inherently different, there is no crisis of trust in the euro at the present time that would justify such increase in target balances» (Committee on Economic and Monetary Affairs, 2016, p. 14).
} 
convenient option, banks in the "periphery" borrowed directly from the Eurosystem.

Therefore, the result was that positive TARGET balances in "core" countries went up, while negative TARGET balances in the "periphery" went down. In conclusion, the Qe liquidity largely went from banks located in the periphery to banks located in the core countries and set there. This also meant that core banks were the ones most penalized by negative rates.

To conclude on this point, we can see that in the first months of 2019, after the conclusion of the EAPP at the end of 2018, TARGET balances stopped to increase further, and began to decrease (see Table 1 ). In fact, the total claims of the three major creditor countries (DE, LU, and NL) decreased from $1271.8 € / \mathrm{b}$ at the end of December 2018 to $1235 € / \mathrm{b}$ at the end of March 2019 . On the other side, the total liabilities of the three major debtor countries (IT, ES, and PT), in absolute terms, decreased from $966.7 € / \mathrm{b}$ at the end of December 2018 to $956.5 € / \mathrm{b}$ at the end of March 2019. This confirms that the increases in TARGET balances in the period from the half of 2014 until the end of December 2018 was due to the EAPP, and that after the conclusion of this programme TARGET balances stopped to increase and have begun to decrease again.

\section{The legitimacy of the ECB's emergency powers inside the European constitutional framework}

A side aspect of the second phase of ECB's quantitative easing monetary policy (Qe2) refers to the formal legitimacy for the ECB to use emergency powers to fight the public debt and banking crises, taking account of the European constitutional framework. In fact, from a juridical point of view, there is a huge debate in literature on this legitimacy, especially about the Outright Monetary Transactions (OMT) programme and the public-sector purchase programme (PSPP). These programmes were seen by some European biggest economies, especially in Germany, as a stealth bailout of indebted South European States, arguing that Northern States' taxpayers had to bear the financial risk for those indebted Countries.

Furthermore, many commentators argued that the PSPP constituted illegal monetary financing, as the Maastricht Treaty forbids direct financing by the ECB to national States, suggesting that the Bundesbank should therefore not participate in the programme. According to the ECB, instead, the questioned programmes were fully within the Bank's mandate to fight any financial crisis risk, and prevented a disintegration of the euro, and of the entire European Monetary Union (EMU).

To solve the institutional conflict, on 15 August 2017, Germany's Constitutional Court (GCC) asked European Court of Justice (ECJ) to make a ruling on the possibility that «the ECB may be violating laws on monetary financing in its 2.3 trillion euro of PSPP». According to the GCC, «significant reasons indicate that the ECB decisions governing the PSPP violate the prohibition of monetary financing and exceed the monetary policy mandate of the ECB, thus encroaching upon the competence of the Member States». ${ }^{17}$

On 11 December 2018, the ECJ rejected the GCC's arguments that the ECB was effectively bankrolling European Governments with its PSPP and sentenced that this programme did not infringe the prohibition of monetary financing to Member States. Further, the ECJ sentenced that the ECB's questioned programmes were in accordance with the European Union law and did not exceed the Bank's mandate (Rios, 2018).

This ECJ ruling ends a long constitutional legal contrast among several European institutions on ECB's emergency powers legitimacy. Anyway, this does not end the debate from a pure theoretical-constitutional point of view. In fact, one of the deepest questions faced by any constitutional order is how to reconcile the possibility of a state of emergency with the ideals of democratic governance and rule of law. This question was raised in a dramatic way as the effects of the global financial crisis regarding the ECB. «The euro became caught up in the destructive vortex of a bank-sovereign doom loop. Unprepared for such events by its legal mandate, the ECB experimented with a wide range of policies measures, which took it to the very limits, if not beyond, the confines of its legal mandate» (van 't Klooster, 2018, p. 270).

Despite explicit prohibitions in its mandate against lending to Member States, during the crisis the ECB spent almost €220 billion on Greek, Irish, Italian, Portuguese, and Spanish bonds. After the crisis, during the Qe period, that is between July 2014 and the end of December 2018, the cumulative net purchases inside the Public-Sector Purchase Programme (PSPP) were 2171 €/b (ECB 2019). This programme, whose permissibility was challenged but ultimately upheld in a 2015 ruling of the European Court of Justice (ECJ), make clear that the ECB has far-reaching, almost unrestrained powers to act in the face of exceptional circumstances. When financial markets hinder its monetary policy, the ECB can do, in Mario Draghi's words, "whatever it takes" to restore financial stability.

The literature on the ECB's emergency powers during and after the European public debt financial crisis is huge. One recent contribution is van 't Klooster's (2018), who describes the emergency powers of the European Central Bank as exercised in the 2010-2012 Eurozone crisis, and raises two objections to the ECB's current powers. First, although the European Court of Justice has sanctioned the creative legal justification put forward by the ECB, the existing powers lack any meaningful democratic basis. Neither the ECB nor the ECJ is in any recognizable sense democratic. The European treaties received democratic consent in entirely different historical circumstances. Second, van 't Klooster shows that the ECB faces almost no constraints on the use of its powers from a legal statute or checks and balances from other political agents. This makes the exercise of the emergency powers available to the ECB objectionably arbitrary. Both objections invoke democratic values which many will accept without doubt for normal circumstances but will be more hesitant to invoke during a state of emergency (van 't Klooster, 2018, pp. 270-271, and pp. 280-284).

In an historical perspective, Schmitt (2005) argued that the exceptional circumstances of a state of emergency are simply incompatible with the ideal of the rule of law. Further, Dicey (2013) argued that even in exceptional circumstances, the rule of law should continue to apply to executive decisions. All that is needed is for the judiciary to provide ex post checks and balances on the

\footnotetext{
${ }^{17}$ See REUTERS, German Challenge to ECB asset buys sent to European Court, available via https://www.reuters.com/article/us-ecb-policy-court/ german-challenge-to-ecb-asset-buys-sent-to-european-court-idUSKCN1AV0PN.
} 
exercise of emergency powers. Against both these schools of thought, van 't Klooster (2018) argues for properly democratic checks and balances on emergency powers and discusses the constitution of the Roman Republic, explaining how emergency powers can remain effective while also subject to democratic checks and balances. At least in the case of the ECB, according to van 't Klooster (2018, p. 271), the possibility of a state of emergency does not require suspension of the rule of law.

With reference to a normative evaluation of the ECB's emergency powers, van 't Klooster raises two objections. First, the ECB lacks a clear democratic mandate for exercising its emergency powers. Second, due to clear legal provisions and its status as an independent institution, the emergency powers can be exercised in a way that is arbitrary. He evaluates three alternative solutions to the democratic deficit created by the ECB's emergency powers and argues for democratic reform. The first proposal is to revise the ECB's legal mandate to enumerate emergency measures to be taken in a sovereign debt crisis. The second is an expanded role of the European Court of Justice in the judicial review of emergency powers. Finally, he argues for a third option, which is to introduce a more prominent role for the EU legislature in the emergency powers procedure. This option is best suited to address existing objections regarding the democratic legitimacy and arbitrariness of the ECB's emergency powers (van 't Klooster, 2018, p. 272).

In this regard, van 't Klooster suggests two options for introducing democratic checks and balances on the ECB's emergency powers. The most democratic procedure on the EU level is that of the ordinary legislative procedure. The legislative procedure requires approval of both the European Parliament (as the direct representative of the European citizens) and the Council of Ministers (composed of members of the elected national governments). Although the independence granted to the ECB by Article 130 of the Treaty on the Functioning of the European Union (TFEU) precludes this procedure having any authority over the ECB, it is possible to amend it so as to make some competences conditional on legislative approval. Therefore, this proposal is called "legislative approval" (van 't Klooster, 2018, pp. 289-290).

A second option is to devise a procedure in which the ECB itself calls the state of emergency, but where the exercise of power is in part delegated to the EU legislature. On such a proposal, after the ECB calls the state of emergency, the EU legislature issues regulations for the ECB to execute. This proposal would involve a more substantial limitation to central bank independence in that the ECB would lose some of its operational independence during a crisis. Following this proposal, it would be up to the ECB to decide that the Eurozone crisis constituted a state of emergency. It would be up to the EU legislature to propose something like the OMT program or the PSPP. So, this proposal is called "legislative power" (van 't Klooster, 2018, p. 290).

According to van "t Klooster, these proposals leave considerable flexibility to the officials that exercise the emergency powers. In both proposals, the decision how to deal with the emergency is not bound by statutes that limit permissible instruments. The exercise of emergency power is also undivided in that, in the proposal for "legislative power", it is either entirely up to the EU legislature or, in the case of "legislative approval", up to the ECB to decide how to deal with an emergency. These proposals thus have the potential to adequately deal with Schmittian (2005) objections. This is not to rule out circumstances in which the very existence of checks and balances leads to gridlock in the political system. Still, the discretion available to political agents must in principle be adequate to deal with the emergency. In this regard, the power of the executive has not been reduced.

Taking account of these proposals, van 't Klooster conclusion is that extending the role of the European legislature in the emergency powers procedure is the most promising way to ensure democratic legitimacy and non-arbitrary exercise of power. It also secures the flexibility needed for adequately dealing with a financial state of emergency. In times of emergency, its mandate gives the ECB powers to do, quite literally, whatever it takes (van 't Klooster, 2018, p. 291).

The disclaimer that the ECB will act within its mandate has limited weight, as almost any measure that addresses a financial crisis can be construed as falling within that mandate. In fact, the exercise of these emergency powers currently lacks an adequate democratic mandate. The status quo also allows for an arbitrary use of emergency powers in that the legal framework allows the ECB to act pretty much as it sees fit. Crucial checks and balances are absent. To address the objections that van 't Klooster raises, a future revision of the European treaties must introduce more extensive legislative checks and balances on the ECB's emergency powers. ${ }^{18}$

In making these arguments, van 't Klooster contributes to three debates. First, from the perspective of earlier debates on the state of emergency and the rule of law, the article puts forward a new account of how to deal with the potential conflict between the needs of a state of emergency and the requirement of democratic government and rule of law. In this regard, he outlines and defends a democratic approach. Second, the article contributes to debates in political philosophy and elsewhere over the future of central bank independence after the Global Financial Crisis. Third, the article contributes to debates over the future of the European Union and its perceived democratic deficit.

\section{Conclusions}

Let us summarize the main points of this article, beginning with how the liquidity is created and destroyed by the NCBs in the euro area. The liquidity, or central bank money (CBM), is created by NCBs whenever they finance the banking system with refinancing operations (MROs, LTROs, and T-LTROs) in a temporary exchange with securities, or when they definitively buy public or private bonds inside the EAPP. For a single country, TARGET balances reflect the sum of the BOP's current account and the capital account, plus the financial account. The CBM so created increases the total amount of liquidity inside the EMU (Fig. 5).

Whenever the CBM comes back to the NCB that issued it (at the end of the temporary refinancing operations, or when the NCB

\footnotetext{
${ }^{18}$ Recent further contributions on the Eurozone crisis and the constitutional basis for EU emergency measures are Lenaerts (2010), Tuori and Tuori (2014), Kilpatrick (2015), White (2015), and Kreuder-Sonnen (2016). A special issue of the European Journal of Political Theory on normative dimensions of the European crisis provides an overview of recent philosophical contributions on the future of the EU (see Ronzoni \& Viehoff, 2017).
} 
sells the bonds previously purchased inside the EAPP, or also when that bond is reimbursed by the Treasury on maturity), it disappears from the NCB's balance sheet.

The CBM can be created only in exchange of a financial activity (loans, bonds, securities, etc.), so the total amount of CBM must be backed by a corresponding amount of financial activities. When these activities will be repaid (the commercial bank repays the loan to the NCB, or the NCB sells the bonds previously purchased inside the EAPP, or finally the Treasury reimburses that bond on maturity), the CBM returns to the NCB that created it and disappears, in the sense that it is cut off from the balance sheet of this NCB.

Inside the EMU, an increase in TARGET balances for a member country is equivalent to an increase in foreign reserves, while a decrease is like a reduction of foreign reserves. For instance, a capital flight to abroad determines a reduction of TARGET balances (which means a smaller credit position or a greater debt position of the involved NCB with respect to the ECB), instead of a reduction in foreign reserves. This means that TARGET balances inside the Eurosystem have the same role as foreign reserves, and any movement in TARGET balances changes the net foreign position of the country in the same way as foreign reserves.

When a capital flight determines an increase of the TARGET debt position of a country, its NCB destroys a corresponding amount of CBM, while at the same time the NCB of the country that receives the foreign capital creates a corresponding amount of CBM. So, the CBM that is destroyed in the first country is exactly re-created in the country where the capital flight is moving to.

Therefore, the liquidity (CBM) created by countries with negative TARGET balances (by MROs, LTROs, and T-LTROs, or by the purchase of bonds inside the EAPP) naturally accrue to countries with positive TARGET balances (because of a surplus in the foreign current account, or of a net import of capital, or of a net selling of bonds inside the EAPP). To some extent, TARGET balances constitute a substitute provided by the ECB for what would normally be private claims among commercial banks, with associated implications in terms of risk shifting from the private sector to the balance sheet of the Eurosystem.

Anyway, inside the EMU, a claim in TARGET does not reflect the relevant NCB's exposure to financial risk. The risk exposure of the central banks forming the Eurosystem relates to the monetary policy operations themselves, not to the associated TARGET balances. These balances can increase without limits and their size does not pose additional risks to the Eurosystem or to the NCBs, given the irreversibility of the euro and the integrity of the Eurosystem. Therefore, any measures designed to contain the size of TARGET balances are not allowed inside the EMU, because they would imply the introduction of other policy objectives alongside the Eurosystem's primary objective of price stability (ECB, 2013, p. 112). And this would imply a change of Maastricht Treaty and/or of the ECB's Statute.

In conclusion, TARGET balances naturally went on increasing as long as the EAPP was in charge, that is until the end of 2018. The liquidity can be re-absorbed any time the ECB decides to sell the bonds purchased inside the Qe program. The liquidity is also reabsorbed any time a bond held by a NCB is reimbursed by the Treasury on maturity.

Now, credit countries banks have an excess of liquidity, which they deposit in the deposit facility of the ECB, paying a negative interest rate. They do not need further liquidity, just because their liquidity is in excess. Therefore, if the EMU is regularly working, and due to the irreversibility of the euro, it is not necessary an annual settlement of TARGET balances from debit to credit countries, as proposed by Sinn and Whelan. ${ }^{19}$

The only case when a member country will be required to settle its TARGET debt is if this country decides to quit the EMU. In fact, according to the ECB's President, Mario Draghi (2017), «If a country were to leave the Eurosystem, its national central bank's claims on or liabilities to the ECB would need to be settled in full». ${ }^{20}$ But he did not specify how this settlement should be done.

In fact, the only way for an EMU's member country to settle its negative TARGET balances is to sell the bonds that back the liquidity created by its NCB and, in so doing, cancel the total CBM that its NCB issued until the moment this country is leaving the EMU. In so doing, some losses could arise because of a possible devaluation of the backing bonds. These potential losses, in turn, should be redistributed among the NCBs of all EMU member States. ${ }^{21}$

Anyway, this scenario is rather hypothetical, because it is not contemplated by the Maastricht Treaty, nor is it by the ECB's Statute, both of which state the irreversibility of the euro. Anyway, also excluding this hypothetical extreme breaking scenario, too much big TARGET imbalances are a manifestation of underlying tensions among member countries in the EMU, highlighting a situation of prevalent one-way direction of the liquidity (CBM) from NCBs with TARGET liabilities to NCBs with TARGET claims. This situation suggests the need for macroeconomic imbalances to be addressed, trust in banking systems to be re-established, and the institutional foundations of EMU to be strengthened. ${ }^{22}$

The EMU continues to suffer from critical weaknesses, but its members are divided on how to address this problem. Maintaining

\footnotetext{
${ }^{19}$ See the previous Sections 4 and 5.

${ }^{20}$ This was Draghi's answer to a question addressed to him by two members of the European Parliament, M. Zanni and M. Valli, who asked how the TARGET balances «would, technically, be settled, especially those in net debtor countries, should a Member State participating in the system decide to quit the single currency?». The letter by Zanni and Valli is available via http://www.europarl.europa.eu/sides/getDoc.do?type= COMPARL\&reference $=$ PE-595.479\&format $=$ PDF\&language $=E N \&$ secondRef $=01$. The extensive Draghi's answer dated 18 January 2017 to those members of the European Parliament is available via https://www.ecb.europa.eu/pub/pdf/other/170120letter_valli_zanni_1.en.pdf.

${ }^{21}$ See footnotes 5 and 11 on this point. In fact, it is not clear how much losses in this exceptional case should be shared by all member States according to the ECB's capital key, or most of them will be attributed only to the quitting country, as it happens for losses due to the Emergency Liquidity Assistance (ELA), quoted in footnote 5.

${ }^{22}$ One of the major macroeconomic imbalances refers to public debt sustainability in the medium and long term, which has become a subject of public debate among EMU countries. The growth of public debt over GDP ratio in some countries (according to the forecasts of the European Commission, at the end of 2018 this ratio was 181.1 percent in Greece, 132.2 in Italy, 97.1 in Spain, and 98.4 in France) poses many threats to this sustainability and to the possibility of maintaining sound public balances in these countries. On this argument, see ECB (2012) and Teică (2012).
} 
the status quo or setting for marginal changes would be a serious mistake, because big TARGET imbalances are a clear manifestation of these weaknesses, including financial fragility, suboptimal conditions for long-term growth, and deep economic and political divisions among EMU member States (Bénassy-Quéré et al., 2018a). At the root of the problem there is a correct balance to reconcile risk sharing and market discipline among these member States. ${ }^{23}$ But this is a different story from interpreting TARGET balances in the EMU, which deserves new investigations and a new article.

Finally, from an institutional point of view, we have discussed on the problem of how to reconcile the emergency powers of the ECB to fight the financial crisis risks with democratic behavior and the rule of law. In this regard, we have analyzed two proposals advanced in the literature, and known respectively as "legislative approval" and "legislative power". The first one consists of the use of the ordinary legislative procedure on the EU level, which requires approval of both the European Parliament (as the direct representative of the European citizens) and the European Council of Ministers. While the second one consists in devising a procedure in which the ECB itself calls the state of emergency, but where the exercise of the emergency powers is in part delegated to the EU legislature.

\section{Appendix A. Supplementary data}

Supplementary data to this article can be found online at https://doi.org/10.1016/j.najef.2019.101039.

\section{References}

Al-Eyd, A., \& Berkmen, P. (2013). Fragmentation and monetary policy in the Euro area, IMF Working Paper n. 13/208, October. Available via http://papers.ssrn.com/ sol3/papers.cfm?abstract_id $=2346258$.

Altavilla, C., Giannone, D., \& Lenza, M. (2014). The financial and macroeconomic effects of OMT announcements, ECB Working Paper Series n. 1707, August. Available via https://www.ecb.europa.eu/pub/pdf/scpwps/ecbwp1707.pdf.

Alvarez, I., Casavecchia, F., De Luca, M., Duering, A., Eser, F., Helmus, C., Hemous, C., Herrala, N., Jakovicka, J., Lo Russo, M., Pasqualone, F., Rubens, M., Soares, R., \& Zennaro, F. (2017). The use of the Eurosystem's monetary policy instruments and operational framework since 2012. Occasional Paper Series n. 188European Central Bank.

Auer, R. (2014). What drives Target2 balances? Evidence from a panel analysis. Economic Policy, 29(77), $139-197$.

Banca d'Italia (2012). Recent evolution of the balances of the TARGET2 payment system. Economic Bulletin, 63.

Bénassy-Quéré A., Brunnermeier, M. K., Enderlein, H., Farhi, E., Fratzscher, M., Fuest, C., ... , Zettelmeyer, J. (2018). How to reconcile risk sharing and market discipline in the euro area, in Vox, CEPR's Policy Portal, available via https://voxeu.org/article/how-reconcile-risk-sharing-and-market-discipline-euro-area.

Bénassy-Quéré A., Brunnermeier, M. K., Enderlein, H., Farhi, E., Fratzscher, M., Fuest, C., ... , Zettelmeyer J. (2018). Reconciling risk sharing with market discipline: A constructive approach to the euro area reform, in CEPR Policy Insight, 91, January, available via http://bruegel.org/wp-content/uploads/2018/01/PolicyInsight 91.pdf.

Bindseil, U., \& König, P. (2011). The economics of TARGET2 balance, SFB 649 Working Paper n. 35. Available via http://sfb649.wiwi.hu-berlin.de/papers/pdf/ SFB649DP2011-035.pdf.

Buiter, W. H., Rahbari, E., \& Michels, J. (2011). The implications of intra-Euro area imbalances in credit flows, CEPR Policy Insight n. 57, August.

Buiter, W. H. \& Rahbari, E. (2012). Target2 Redux: The simple accountancy and slightly more complex economics of bundesbank loss exposure through the eurosystem, CEPR Discussion Paper n. 9211. Available via http://www.willembuiter.com/target2redux.pdf.

Cecioni, M., \& Ferrero, G., (2012). Determinants of TARGET2 imbalances, Banca d'Italia, Questioni di Economia e Finanza (Occasional Papers), 136, September.

Committee on Economic and Monetary Affairs (2016). Monetary Dialogue with Mario Draghi, Monday, 28 November. Available via https://www.ecb.europa.eu/ press/key/date/2016/html/sp161128_1_Transcript_and_QandA.en.pdf?a3cfb1ef2628076b85170d60ff935127.

De Grauwe, P., \& Ji, Y. (2012). What Germany should fear most is its own fear, Vox, September 18. Available via http://www.voxeu.org/article/how-germany-canavoid-wealth-losses-if-eurozone-breaks-limit-conversion-german-residents.

Demiralp S., Eisenschmidt, J., \& Vlassopoulos, T. (2017). Negative interest rates, excess liquidity and bank business models: Banks' reaction to unconventional monetary policy in the euro area, Working Paper Series n. 1708, Koç University-Tüsiad Economic Research Forum, March. Available via http://eaf.ku.edu.tr/sites/ eaf.ku.edu.tr/files/erf wp_1708.pdf.

Dicey, A. V. (2013). The law of constitution. Oxford: University Press reprint of the 1885 edition.

de Sola Perea, M., \& van Nieuwenhuyze, C. (2014). Financial integration and fragmentation in the euro area. NBB Economic Review June 99-125.

Deutsche Bundesbank (2011). The dynamics of the bundesbank's TARGET2 balances, Monthly Report, March, vol. 63.

Deutsche Bundesbank (2016). The impact of Eurosystem securities purchases on the TARGET2 balances, in Monthly Report, March, vol. 68.

Draghi, M., (2015). Interview with Die Zeit, January 15. Available via https://www.ecb.europa.eu/press/inter/date/2015/html/sp150115.en.html.

Draghi, M. (2017). Re: Your letter (QZ-120), 18 January 2017. Available via https://www.ecb.europa.eu/pub/pdf/other/170120letter_valli_zanni_1.en.pdf? be6aea5c0aa3596d1d08149b510ea707.

ECB (2011). TARGET2 balances of national central banks in the euro area. Monthly Bulletin October, Box 4.

\footnotetext{
${ }^{23}$ Bénassy-Quéré et al (2018a) summarize this problem as follows: «The 'doom loop' between banks and sovereigns continues to pose a major threat to individual member states and the euro area as a whole. An incomplete banking union and fragmented capital markets prevent the euro area from reaping the full benefits of monetary integration and from achieving better risk sharing through market mechanisms. Fiscal rules are nontransparent, pro-cyclical, and divisive, and have not been very effective in reducing public debts. The flaws in the euro area's fiscal architecture have overburdened the ECB and increasingly given rise to political tensions. The euro area's inability to deal with insolvent countries other than through crisis loans conditioned on harsh fiscal adjustment has fuelled nationalist and populist movements in both debtor and creditor countries. The resulting loss of trust may eventually threaten not just the euro, but the entire European project». A comprehensive document by the same Authors proposes to address to Eurosystem's member countries a package of the following six main elements: first, breaking the vicious circle between banks and sovereigns through the coordinated introduction of sovereign concentration charges for banks and a common deposit insurance; second, replacing the current system of fiscal rules focused on the 'structural deficit' by a simple expenditure rule guided by a long-term debt-reduction target; third, allowing orderly sovereign debt restructuring of countries whose solvency cannot be restored through conditional crisis lending - and hence a more credible no bailout rule; fourth, creating a euro area fund, financed by national contributions, that helps participating member countries absorb large economic disruptions; fifth, an initiative to create a synthetic euro area safe asset that would offer investors an alternative to national sovereign bonds; and sixth, a reform of the euro area institutional architecture (Bénassy-Quéré et al., 2018b).
} 
ECB (2012). Analysing Government debt sustainability in the euro area. Monthly Bulletin, April, 55-69.

ECB (2013). TARGET balances and monetary policy operations. Monthly Bulletin, May, 103-114.

ECB (2015). Publication of TARGET balances. Economic Bulletin, 6, 42-44 Box 4.

ECB (2016). TARGET balances and the asset purchase programme. Economic Bulletin November, Box.

ECB (2017a). Analyzing euro area net portfolio investment outflows. Economic Bulletin, 41-45 Issue 2.

ECB (2017b). The ECB's asset purchase programme and TARGET balances: Monetary policy implementation and beyond. Economic Bulletin May, Boxes.

ECB, (2019). Asset purchase programmes, available via https://www.ecb.europa.eu/mopo/implement/omt/html/index.en.html.

Eisenschmidt, J., Kedan, D., Schmitz, M., Adalid, R., \& Papsdorf, P. (2017). The Eurosystem's asset purchase programme and TARGET balances, Occasional Paper Series, n. 196, European Central Bank, September.

European Commission (2013), Annual growth survey, Brussels, 28.11.2012.

Gilchrist, S., \& Mojon, B. (2014). Credit risk in the euro area, NBER Working Paper n. 20041, April. Available via http://www.nber.org/papers/w20041.

Kaminsky, G. L., \& Reinhart, C. M. (1999). The twin crises: The causes of banking and balance-of-payments problems. American Economic Review, 89(3), 473-500.

Kilpatrick, C. (2015). On the rule of law and economic emergency: The degradation of basic legal values in Europe's bailouts. Oxford Journal of Legal Studies, 35(2), 325-353.

Kreuder-Sonnen, C. (2016). Beyond integration theory: The (anti-) constitutional dimension of European crisis governance. Journal of Common Market Studies, 54, $1350-1366$.

Lenaerts, K. (2010). The contribution of the european court of justice to the area of freedom, security and justice. International and Comparative Law Quarterly, 59(2), $255-301$.

Martínez Pagés, J. (2016). The eurosystem's quantitative easing measures and the financial account. Economic Bulletin Banco de España, April 3-13.

Moro, B. (2014). Lessons from the European economic and financial great crisis: A survey. European Journal of Political Economy, 34 Supplement June, S9-S24.

Moro, B. (2016). The European crisis and the accumulation of TARGET2 balances. In B. Moro, \& V. Beker (Eds.). Modern financial crises: Argentina, United States and Europe (pp. 107-133). Heidelberg: Springer.

Rios, B., (2018). EU top court rules in favor of Drag's bond-buying programme, in EURACTIVE.com, available via https://www.euractiv.com/section/economy-jobs/ news/eu-top-court-rules-in-favor-of-draghis-bond-buying-programme/.

Ronzoni, M., \& Viehoff, J. (2017). Introduction: Normative dimensions of the European crisis. European Journal of Political Theory, 16(2), 139-142.

Sinn, H. W. (2011). The ECB stealth bailout, VoxEu, June 1.

Sinn, H. W. (2012). Fed versus ECB: How target debt can be repaid, Vox, March 10. Available via http://www.voxeu.org/article/fed-versus-ecb-how-target-debts-canbe-repaid.

Sinn H. W. (2012), "TARGET Losses in Case of a Euro Breakup", Vox, October 22.

Sinn, H. W., \& Wollmershäeuser, T. (2011). Target loans, current account balances and capital flows: The ECB's rescue facility, NBER WP n. 17626, November.

Sinn, H. W., \& Wollmershäeuser, T. (2012). Target balances and the German financial account in light of the European balance-of-payments crisis, CESifo Working Paper n. 4051. Available via http://www.cesifo-group.de/DocDL/cesifo1_wp4051.pdf.

Schmitt, C. (2005). Political theology: Four chapters on the concept of sovereignty. Chicago: University Press.

Teică, R. A. (2012). Analysis of public debt sustainability in the economic and monetary union. Procedia Economics and Finance, 3, 1081-1087 Available via https:// ac.els-cdn.com/S2212567112002778/1-s2.0-S2212567112002778-main.pdf?_tid = b87050ff-1e1a-45d3-be0e-7626f49075b18acdnat=1522866856_58131ba5957e72c630693ef5b1062cb0.

Terzi, A. (2015). More Target2 divergence: This time is different. Money and the Real Economy October 24. Available via http://www.ateconomics.com/2015/10/24/ more-target2-divergence-this-time-is-different/.

Tuori, K., \& Tuori, K. (2014). The Eurozone crisis: A constitutional analysis. Cambridge: University Press.

Van Rixtel, A. A. R. J. M., \& Gasperini, G. (2013). Financial crisis and bank funding: Recent experience in the euro, BIS Working Paper n. 405, March.

van 't Klooster, J. (2018). Democracy and the European central bank's emergency powers. Midwest Studies in Philosophy, 42(1), 270-293 Available via https:// onlinelibrary.wiley.com/doi/full/10.1111/misp.12094.

Whelan, K. (2011). Professor Sinn Misses the target, VoxEu, June 9. Available via http://www.voxeu.org/article/there-hidden-eurozone-bailout.

Whelan, K. (2012). TARGET2 and central bank balance sheets. University College Dublin, School of Economics WP n. 12/29, November. Available via http:// www.ucd.ie/t4cms/WP12_29.pdf.

Whelan, K. (2014). TARGET2 and central bank balance sheets. Economic Policy, 29(77), 79-137.

White, J. (2015). Emergency Europe. Political Studies, 63(2), 300-318. 